\title{
Dressing for Power: On vrata, caryā, and vidyā vrata in the Early Mantramārga, and on the Structure of the Guhyasūtra of the Niśvāsatattvasaṃhitā
}

\author{
Dominic Goodall
}

If, twenty years ago, you had read most of the literature published before the 199os about the Śaivasiddhānta, you would probably have received the impression that this was primarily a South Indian movement, whose scriptures, called àgamas, were divided into four sections, or pādas, devoted to ritual $(k r i y \bar{a})$, doctrine (jñāna), yoga and pious conduct (caryā). The first two of these four sections, the kriya $\bar{a}-p \bar{a} d a$ and the jiñana-pāda, you would have learnt, were the most important, the kriyāpāda being devoted to describing the rituals practised in the Śaiva temples of the Tamil-speaking area, and the jñannapāda (or vidy $\bar{a}$ pāda) being devoted to teaching and defending a strictly dualist system that presents an ontological ladder of thirty-six tattvas, but that recognises three irreducible ontological categories: pati, paśu and pāśa. That is to say: the Lord (pati), bound souls (paśu), and the bonds that bind them (pāśa), namely Matter, karman and an innate impurity called mala or ạnava-mala.

Each one of these pieces of received wisdom has been challenged by the discoveries of the last two decades, so that we now know that none of the above propositions actually holds true for the earliest strata of the religion to which surviving primary literature can give us access. A great many of those discoveries are those of Alexis Sanderson and the students to whom for decades he devoted much of his time and energy.

Of course it is wide reading of a very broad corpus of published and unpublished sources that has gradually revealed to us quite a different picture of the early phases of the religion. But if one were to single out any one text for its importance in expanding our knowledge of the early history of the Mantramārga, it would probably be the Niśvāsatattvasaṃitā.

Ten years ago, hardly any aspect of the text had been explored in print, but, thanks in part to the spotlight of the Franco-German 'Early Tantra' project, which between 2008 and 2011 focussed the minds of many people present at the Toronto symposium on the Niśvāsa and on its relation to other early tantric literature, parts of the work have been commented upon in an array of publications. The first major arcticle actually predates the 'Early Tantra' project, and is, 
of course, by Professor Sanderson himself: it is his study of the Lākulas (2006). Apart from the first volume of the collaborative edition and translation, covering the earliest three books of the Niśvāsa-the Mūlasūtra, Uttarasūtra and Nayasütra - there are now substantial articles on, for instance, the evolution of the system of tattvas that can be traced as it gradually takes shape within the Niśvāsa-corpus (Goodall 2016), and on the lengthy grimoires of magical rites contained in the Guhyasütra that are similar in style and content to those found in Buddhist kriyattantra works, and most strikingly similar to the those in the Mañjuśriyamūlakalpa (Goodall and Isaacson 2016).

Now that the earliest three books of the Niśvāsa are published at last, and now that the introductory book, the Niśvāsamukhatattvasaṃhitā, has been thoroughly examined in a doctoral thesis defended this year at the University of Leiden by Nirajan Kafle $\left(2015^{*}\right)$, what remains is the largest book of them all: the Guhyasütra. The ninth-century manuscript of the corpus (NGMPP Reel No. A 41/14) comprises 114 folios, and all of the hitherto edited works together cover only the first 40 of those. The remaining 74 folios give us the text of the Guhyasūtra. Here is a very brief outline of the structure of its eighteen chapters:

\section{A. SĀD HANA}

Ch. 1 personality-types of sādhakas and types of lingas that may be used for siddhi.

Ch. 2 lingapratișthā.

Ch. 3 preparations for sādhana, prognosticatory rites, vratas, procedures for attaining certain siddhis.

\section{B. Cosmography}

Chs. 4-7 a lengthy cosmography (prakriyājñāna).

Ch. 8 a variant form of $d \bar{\imath} k s \bar{a}$ in the form of worship of a series of mandalas peopled by deities of the different levels of the cosmos (prakriyāyāga).

\section{Other Mantra-Systems}

Finally, the use, primarily for magical powers, of mantra-systems other than those given in the earlier three sūtras, namely

a) Chs. 9-11 The vyomaryāpin.

b) Chs. 12-14 The five brahmamantras.

Ch. 15 Long forms of their angamantras.

c) Chs. 16-18 A ten-syllable mantra called vidyā.

The Guhyasūtra is somewhat like a series of appendices to the earlier sūtras, containing more detailed accounts of some topics that have already been cov- 
ered (cosmography), but also entirely new subjects (new mantras) or treatments of subjects that have hitherto only been alluded to, notably the acquisition of siddhis. As I have tried to indicate with the overarching titles (A, B, C) in the brief summary above, I think that it can be said that chapters 1 to 3 have a certain sort of unity because they cover the acquisition of magical powers in much greater detail than we see in earlier layers of the text: the first chapter gives information about sädhakas, then stresses the importance of the linga for attaining siddhis, after which, in chapter 2, the installation of lingas is covered, and then in the third chapter we return to the preparations for sädhana and finally the procedures to be followed. Chapters 4-7 then give us a very detailed account of the Śaiva cosmos, the higher reaches of which have been further expanded and embroidered upon since the composition of the earlier sūtras of the text. ${ }^{1}$ This is undertaken because dīkșa involves purging the soul of the fruits of karman that would need to be experienced-and thus expended-through every layer of the Śaiva universe. Using the same cosmography, chapter 8 describes an alternative dīkșa involving the worship of mandalas representing successive layers of the universe, and it then contains a number of add-on discussions that suggest, it seems to me, that the text once drew to a close at that point, as we shall see below. What follow, taking us up to the end of the Guhyasütra, are three distinct textual layers each devoted to introducing an extra mantra-system, namely 1) that of the 81-word VYOMAVYĀPIN, 2) that of the brahmamantras, and 3) that of the ten-syllable VIDYĀ. To each of these is attached a grimoire of magical recipes (kalpa).

Turning to the conclusion of chapter 8 , I think that we can see from the summary given below that it reads like a series of codas. Verse 105 gives a clear statement of what we are supposed to have learnt from the preceding chapters, and it is followed immediately by remarks about the persons to whom these teachings may and may not be submitted, a typical closing device. Tagged on to this, from verse 116 onwards, is a treatment of religious suicide, again a theme suitable to the conclusion of a work of scripture. The final section, from verse 125, is introduced by Devi's question about the status of rival religious traditions. In answer, Śiva explains that He and Devī, as consonants and vowels, are the source of all language, and that they are the source of all the universe in that they are to be identified with the various tattvas from which all else evolves.

1 A full examination of this embroidery will have to await the publication of the relevant parts of the Guhyasütra, but some idea of its extent and nature may be gained from the table on pp. 290-293 of Goodall, Sanderson and Isaacson 2015 and from the surrounding annotation, as well as from Goodall 2016. 
Summary of the conclusion of Guhyasūtra $8:^{2}$

8.88-89 Devī asks how an initiate may foretell his own death.

8.90-98 Śiva recounts signs of death.

8.99-104 Activities that can be done under particular asterisms that grant release [from death?].

8.105 Summary of teachings from chapter 4 up to this point in chapter 8 .

8.106-110 Those to whom one should and should not transmit this knowledge.

8.111-114b The 4 means of liberation: dīkșā, jñāna, yoga, caryā.

8.114c-115 One should transmit this only to someone worthy.

8.116-117 Devī asks about religious suicide.

8.118-122 Śiva deprecates death in tîrthas for initiates; he teaches instead 5 varieties of a 'razor'-mantra for suicide by japa.

8.123 Increasing length of life by yogic dhäranās.

8.124 The supreme Śaiva knowledge, without which one cannot be liberated, has been taught!

8.125-127 Devi asks about the fate of those who follow rival religions. 8.128-133 Siva explains that He and Devī, as the consonants and vowels of the alphabet, are the source of all linguistic expression ( $v \bar{a} \dot{n}$ mayam) and of all that has evolved (vikārāh).

8.134-136 The MŪLA-mantra is a panacea (mrrtasañjīivani) .

8.137-138 Śiva and Pārvatī are parents of everything in that they are respectively these tattvas: puruṣa and prakrti; kāla and niyati; iśvara and māyā+vidyā; sadāśiva and kalā.

8.139-140 They are also respectively [supreme] Śiva and His Will (icchā).

8.141 Those who do not know the NAVĀTMAN, who are devoid of dīkșa and jñāna, who do not know the MŪ LA, do not attain the highest state.

2 Much of this conclusion has, by the way, been borrowed and adapted into the Niśvāsakārikā, which seems itself like another series of addenda that further modify and extend the teachings of the sūtras of the Niśvāsatattvasamhitā. Thus Guhyasūtra 8.88-89 and 8.92-104 have been reworked to produce chapter 21 of the jñānakāṇ 133; T. 127, pp. 36-38); and Guhyasütra 8.125-136 have been reworked to form the beginning of chapter 20 (23 in T. 127) of the jñānakānda of the Niśvāsakārikā (T. 17, pp. 122-124; T. 127, pp. 231-233). The chapter continues, at least in T. 17, for a further 32 verses on rival notions of liberation and methods for attaining it. 
We may remark in passing that a noteworthy feature of this final passage is that the text takes no clearly defined position on the debate between dualism, which was to become a defining characteristic of classical mainstream Saiddhāntika doctrine, and non-dualism: it seems as though this debate had not yet caught the interest and attention of Saiva thinkers. Here is the passage in question:

ahaṃ pumāṃs tvaṃ prakṛti niyati puna[[r eva ca]]
niya---[2] kālarūpī maheśvarah 8.137
tvam māyā ca tathā vidyā aham punas tatheśvarah
sadāśiva ahan devi tvañ caturdhā kaleśvarī 8.138
ísitvāc ca vaśitvāc ca sarvajñatvāc ca nityaśah
śāntatvān niṣkalatvāc ca samatvāc ca aham śivah 8.139
mama icchā na hanyā tvaṃ tvaṃ hi śaktibalodayā
tvatsūtañ ca jagat sarvam śivadā sadanugrahe $\quad 8.140$

I am puruṣatattva and you are prakrti and also niyati; ... Maheśvara is Time; you are Māyā and Vidyā, while I am İ́sara-tattva. I, O goddess, am Sadāśiva [and] you are mistress of the 4 kalās. (137-138)

Because I rule, I control, I am omniscient, because I am permanently at rest, without division and in equilibrium, I am Śiva. (139)

You are my Will, not to be crossed, for you are the one from whom the power of the śaktis arises!

The whole universe has sprung from you; You bestow Śiva-nature, O you of true compassion! (140)

Having proposed an identification of the principal layers of redaction that are detectable in the Guhyasūtra, I should like now to skip back to the verses in the conclusion of chapter 8 that speak about those to whom the teachings may and may not be transmitted, since these verses bear both upon the themes that structure the work and upon the subject of carya $\bar{a}$. For, slipped into the middle of that section, beginning in verse 8.111 , is a short sequence of verses that make the claim that the teachings of the text comprise four independently salvific parts: dīkșā, jñ̄ana, yoga and caryā.

etad buddhvā na dātavyaṃ śivadevāmṛtam param $\quad 8.110$ dīkṣājñānena yogena caryayā ca yathākramam pratyekaśah śivāvāptis tantre 'smin pārameśvare 8.111 dīkṣayā sukaraṃ mokṣaṃ yad gurus sādhayet sadā jñānañ ca gurum āsādya labhyate tat[[prasādataḥ]] $\quad 8.112$ 
---[f. 72r] te $\mathrm{mx}$ yo $\mathrm{xx}\left(\right.$ ?) ca gurupādatah ${ }^{3}$

ātmaśaktyā carec caryāṃ sarvasiddhipradāyikām $\quad 8.113$

etac catușțayam proktaṃ sạ̣sārabhayanāśanam

parasyaiva na deyan tu yadi 'cchet siddhim ātmanah $\quad 8.114$

Knowing this, one should not give [lightly] the supreme nectar of Lord Śiva. (110)

According to this scripture of the Lord, one may attain Śiva by each of the following [practised individually] (pratyekaśah): initiation, knowledge, yoga and caryā in due order. (111)

By initiation one attains liberation easily, since it is the guru who invariably accomplishes it. ${ }^{4}$ And knowledge is obtained, once one finds a guru, through his grace. (112)

... yo[ga] ... from the feet of the guru; One must practise carya $\bar{a}$, which bestows all supernatural powers, using one's own strength (ätmaśaktyā). (113)

This tetrad has been taught to destroy the dangers of samsāra. It should not [lightly] be given to others if one desires supernatural power for oneself. (114)

An innocent might here at first suppose that we find here what may be the earliest allusion to the notion that each Śaiva scripture should be arranged in four text-units called pādas, for it is not difficult to see that the kriyāpāda might easily be referred to by the most significant ritual of all, namely dīkșa. Now Brunner (1992) and others ${ }^{5}$ have shown that most early scriptures are not in fact divided into four such text-units, and the Niśvāsa certainly is not. Nonetheless, one might reasonably suppose that the four topics to which some later scriptures devote four text-sections called $p \bar{a} d a s$ are referred to here. But are they? Plainly the first three, dīkșa, jñ̄ana and yoga, may be found treated at length in the Niśvāsa; but is there anything that we might recognise as carya ? This is a word we are rather used to seeing translated as "conduct" or "comportment," as for instance in the title of Brunner's 1985 translation of the kriyappāda and caryāpāda of the Mrgendratantra: Mrgendrāgama[.] Section des rites et section $d u$ comportement. When she characterises the content of the caryāpäda there, she observes (p. xxxvii):

3 Perhaps N once read: yogañ ca gurupādatah?

4 At the beginning of the kriyāpa a da of the Matanga (1.2), initiation is similarly presented as an alternative route to salvation that is easier than taking the more difficult path of jñanna.

5 See Goodall 1998, lviii-lxv. 
La presque totalité de l' exposé (śl 1-105) est consacrée à un sujet unique: le comportement normal des différents groupes d'initiés. ${ }^{6}$

This is a topic that we really do not find addressed in the Niśvāsatattvasaṃitā, and it is therefore clear that carya probably does not mean "comportement normal" in this text. When speaking in Toronto, I was unaware that Christian Wedemeyer, faced with similar difficulties of interpretation resulting from assuming such a meaning, had already devoted a chapter of his work on Making Sense of Tantric Buddhism (2013, 133-169) to discussing how caryā and related terms should be understood in early Buddhist and Śaiva tantric works. ${ }^{7}$ An exploration of this theme therefore now seems in some respects less pressing to me than it once did. But there are still some issues that can usefully be commented upon, and there are several early Śaiva attestations of the nexus of caryā-related terms of which Wedemeyer was not aware and which serve to adjust, I think, some of what he has said about this semantic field, and that go some way to explaining a significant juncture in the semantic voyage of the term carya that led to its being commonly assumed in modern scholarship to mean something like "comportement normal," even in passages in which such a meaning does not fit. Wedemeyer's account does clarify a number of confusions, and he is to be commended for taking into account several Śaiva passages, but a combination of a desire to show that it is the Saivas who have borrowed from the Buddhists rather more than the Buddhists have from the Saivas here (2013, 136-137, 154) and of not having had access to the earliest known Śaiva material (which I should like to have made widely available long ago, but editing concurrently the Niśvāsa, the Kirana and the Sarvajñannottara is proving a very time-consuming project) have led him to some problematic assertions and assumptions, some of which I hope to correct below. ${ }^{8}$ In what follows, I will

6 "Almost the entire exposition (verses 1-105) is devoted to a single subject: the regular comportment of different groups of initiates."

7 I am grateful to Tim Cahill for bringing Wedemeyer 2013 to my attention by kindly giving me a copy when he was visiting Pondicherry in 2015 .

8 John Nemec too expresses some reserves in his generally positive review $(2014,272-273)$ and encourages further investigation of the Śaiva understanding of vratas:

Even if we grant that Wedemeyer limits his argument to instances of the antinomian practices that were understood to lead to liberation through a nondualistic, epistemological, or gnostic insight, as I think he wishes to do, there is nevertheless some work left to be done, in my view, to prove that even this particular understanding of the rites in question originated with tantric Buddhism (and the Guhyasamäjatantra in particular [16o$162,166])$. What is needed is a more thorough effort to establish the relative chronology of the relevant texts and, more importantly, a more detailed account of the Śaiva selfunderstandings of the religious observances in question. 
be expanding upon and shoring up what was advanced rather too tentatively in a lengthy note on Mūlasütra 4.17c-18 (Goodall, Sanderson, Isaacson et al. $2015,284-287$ ).

In fact, the basic difficulty with the central term caryā had arguably already been resolved, in nuce, by Alexis Sanderson in his 2006 article on the Lākulas, but in a somewhat laconic fashion. What he writes, just before presenting the vratas in the ninth chapter of the caryāpāda of the Matangapārameśvara, is the following:

The Śaivas have conventionally divided the means of liberation taught in the Āgamas, that is to say their subject matter, into the four categories, ritual (kriȳa ), doctrine or gnosis (jñannam, vidyā), meditation (yogaḥ), and ascetic observance and other rules governing the conduct of the various classes and kinds of initiate $(c a r y \bar{a})$. Continuities between the Lākulas and the Śaivas have now been shown in the areas of the ritual of initiation and in the doctrine of the path to liberation, [...] Insufficient evidence exists to permit much of a comparison in the domain of meditation. [...] This leaves only the domain of ascetic observance (vratacaryā).

It is clear, in other words, that caryā, in early Śaiva works, may refer specifically to ascetic observance, presumably indeed because it is a contraction of the collocation vratacaryā/vratacarana, "the performance (caryā/carana) of timed religious observances (vrata)." The verb car, "to move," but also "to be engaged in," has indeed long been the natural idiomatic verb of choice for use with $v$ rata, and this accounts for the frequency of such bahuvrihi expressions as cirnavrata ("who has observed his observances"), both in non-Mantramārga works (e.g. Bodhāyanagrhyasūtra 4.12.2 on p. 118, Yājñavalkyasmrrti 3.298c, Mahābhārata 3.81.135c) and in works of the Mantramārga (e.g. Mãlinivijayottara $10.17 \mathrm{c}$ and 10.34c, Mohacüdottara 1.14a, etc), as well as for the distinctively tantric bahuvrïhi expression cirnnavidyāvrata (e.g. Siddhayogeśvarimata 13.1a), ${ }^{9}$ to which we shall return below.

9 One non-tantric instance has been pointed out to me by Harunaga Isaacson (email of 26.xii $.2015)$.

... I find one occurrence of cirnavidyāvrata in a non-tantric text and a non-tantric context. It is in Vyomaśiva's Vyomavatī, the oldest of the commentaries on the Padārthadharmasamgraha (perhaps early 1oth century; might be even slightly earlier). Of course, even though the context is here of orthodox Vedic/brahmanical practice, we can be pretty certain that Vyomaśiva, as his name already suggests, was familiar with the Siddhānta and 
If we were concerned only with the meanings of the word carya $\bar{a}$, then it might seem that we could almost end our essay here: Wedemeyer has pointed out that carya $\bar{a}$ conventionally refers to virtuous behaviour and conduct in accordance with religious precepts in a number of early non-tantric Buddhist texts $(2013,135)$, where he characterises it as "by far the most common generic term for the spiritual undertakings of buddhas and bodhisattvas," just as it does in much later Śaiva works of the Mantramārga, such as the Mrgendra; Sanderson has alluded (in the passage just quoted) to the observed fact that it may refer in Śaiva sources both to the prescribed "conduct of the various classes and kinds of initiate" as well as to "ascetic observance," and he has pregnantly suggested that this second meaning is connected with the notion of vratacaryā; finally, Wedemeyer has observed that caryā in Buddhist tantric sources, and in some Śaiva ones, refers not to life-long virtuous conduct, but rather to timed antinomian practices, in troubling places such as cremation grounds and involving transgressive sexual and mortuary elements.

But, as my title indicates, there is in fact a nexus of terms to be examined here. Wedemeyer indeed points out that there are several other related terms that seem to be used in places where carya might have served instead, caryāvrata and vratacaryā being apparently "used with identical meaning" $(2013,136)$, to which he adds instances of these words "in compound with qualifiers related to ideas of secrecy or madness," such as guhyavrata, guhyacaryā, prachannavrata, unmattavrata, and "a cluster of interrelated terms that appear in the same contexts, and which seem to be largely synonymous," which he tabulates on p. 137. Among these, he singles out vidyāvrata, for which he suggests the translations "knowledge observance, spell observance, and/or consort observance" $(2013,136)$ as being "treated as essentially equivalent to caryāvrata/vratacaryā in Buddhist and Śaiva sources."

Now it may indeed be the case that several of these terms appear to be used interchangeably, but a slightly broader and chronologically deeper slice of Śaiva samples reveals, it seems to me, both how the terms in fact differ from each other and also why it is that they may in some contexts appear to be interchangeable, while at other times they are not. This may seem hair-splittingly tedious, but, as Wedemeyer points out, if we do not understand the words, then we cannot understand what it is that they serve to express. ${ }^{10}$ The Viennese

quite likely other forms of Śaivism, so there is a chance that his terminology has been unconsciously influenced by tantric usage.

In the passage in question, on p. 233 of the edition, Vyomaśiva is glossing Praśastapāda's use of the term vidyāvratasnätaka. 
endeavour that has so far produced three out of five volumes of the Tāntrikābhidhānakośa is a step towards a better understanding of technical terms and of common terms used with technical senses in the literature of the Mantramārga, even if it does not, alas, cover Tantric Buddhist literature."

Turning to the Viennese dictionary for an understanding of carya $\bar{a}$ is, however, not yet particularly useful, for the entry under this word consists only of a cross-reference to the term caryāpa $\bar{a} d a$. But the account of that term does contain what will one day be a useful cross-reference to a future article on the term $v r a t a$, and it includes one useful pointer to a moment in the history of the term caryā:

Note that vrata is substituted as a synonym for carya $\bar{a}$ in Kir[ana] 6.6c; indeed it is conceivable that the term is an abbreviation of vratacary $\bar{a}$ (Kir[ana] 49.4).

The volume of the Tāntrikäbhidhānakośa in question appeared back in 2004; by the time the fifth volume appears, including the terms vrata and vidyāvrata, this dictionary will be a still more useful resource for tracing out the shifting semantics of this and many another nexus of tantric terms.

Let us follow up this reference to the Kiranatantra. Since its chapter, 49, on vratacary $\bar{a}$ is short, we may quote much of it below, omitting from the middle a detailed treatment of the ideal kamandalu, and giving just the readings of the Devakottai edition $\left(\mathrm{E}_{D}\right)$ and the Nepalese manuscript of $924 \mathrm{AD}$ (N, f. 7or):

garuḍa uvāca-

samayī putrakaś cāpi deśikaś ca maheśvara

eșāṃ vṛttiḥ samākhyātā sādhakasya bravīhi me $\quad 49.1$

bhagavān uvāca-

sādhakah sātviko dhīrạ̣ sahiṣnur mantradhīr varạ̣

apradhṛ̣syo mahāprājñaḥ samaloșțāśmakāñcanah $\quad 49.2$

udyukto homanișțhaś ca japadhyānarataḥ sadā

cerned with understanding the meanings of common words that are used with technical senses $(2013,134)$ : "Recognition of these terms as terms of art is, however, essential, insofar as failure in this regard creates and sustains broad and systemic misinterpretation of Tantric literature and of the traditions that produced (and were, in turn, produced by) these works."

11 The desirability of covering Buddhist Tantric literature is alluded to in the preface to the third volume (p. 11), but it is obvious that the project cannot be simply "tweaked" at this late stage to incorporate a huge extra corpus only in volumes 4 and 5 . 
vighnaprotsāraṇe kalyo vratanișțhạ̣ samạ̣ śuciḥ sasakhāyo vanaṃ gatvā vratacaryāṃ samārabhet asahāyo tadā tasmiṃ svasakhāyaḥ kamaṇụaluḥ

Iab samayī putrakaś cāpi deśikaś ca] $\mathrm{N}$; samaȳisūtayoś cāpi deśikasya $\mathrm{E}_{D} \bullet 1 \mathrm{~b}$ maheśvara] $\mathrm{E}_{D}$; maheśvaraḥ $\mathrm{N}$ • 1c eșāṃ vṛttiḥ] $\mathrm{E}_{D}$; eșā vṛtti $\mathrm{N}$ • 2a sādhakah sātviko dhīraḥ] $\mathrm{E}_{D}$; sādhaka sātviko dhīra $\mathrm{N} \bullet 2 \mathrm{~b}$ varaḥ] $\mathrm{E}_{D}$; vara $\mathrm{N}$ • 2c apradhṛsyo] $\mathrm{E}_{D}$; apradṛșyo $\mathrm{N}$ • $3^{\mathrm{c}}{ }^{\circ}$ protsāraṇe] $\mathrm{E}_{D}$; ${ }^{\circ}$ procchāraṇe $\mathrm{N} \cdot{ }^{3 \mathrm{~d}}$ śuciḥ] $\mathrm{E}_{D}$; śucit $\mathrm{N} \quad \bullet$ 4a sasakhāyo] $\mathrm{N}$; sasahāyo $\mathrm{E}_{D} \bullet 4$ b vratacaryāṃ samārabhet] $\mathrm{E}_{D}$; vratācaraṇam ārabhet $\mathrm{N} \cdot 4 \mathrm{~cd}$ tadā tasmiṃ svasakhāyaḥ] em.; tadā tasmiṃ svasakhāya ${ }^{\circ} \mathrm{N}$; yadā tasmin susahāyaḥ $\mathrm{E}_{D}$

Garuḍa spoke:

You have taught me, $\mathrm{O}$ great Lord, the activities of the neophyte, the putraka and the ācārya. Tell me those of the sādhaka. (1)

The Lord spoke:

The excellent (varah) sādhaka [should be] full of sattva, firm, capable of endurance, his mind fixed on [his] mantra, unassailable, of great wisdom, looking impartially on mud, stones and gold, (2) engaged, regular in [the performance of] oblations, always devoted to recitation and meditation, dexterous in the dispelling of obstacles, firm in [the practice of his] religious observance, calm, pure. (3) Accompanied by his ritual assistant, he should go to the forest and begin the practice of his religious observance (vratacaryām). [If he is] without a ritual assistant, then his spouted water-pot is his ritual assistant in that [practice]. ${ }^{12}(4)$

\section{[Description of spouted water-pot omitted.]}

saśalyas tumbako vā syād evaṃ kṛtvā vratañ caret jațāmakuṭasāțopam śūlakhațvāngalāñchitam śuddhamuṇ̣ārdhasamyuktam tṛlocanakṛtādaram

49.13

12 This idea that the sādhaka, when embarking on the pursuit of supernatural powers, must be accompanied either by a ritual assistant or by his water-pot is expressed elsewhere too, for instance in Sarvajñannottara 25.19: susakhāyo yadā mantrī mantrasādhanam ārabhet asakhāyo yogī siddhị̣ kamaṇ̣̣alukaraḥ sadā $\quad 19$

19a susakhāyo yadā] N; ப sāyo yadā L •19c asakhāyo yogī siddhiṃ] conj.; asākhayogasiddhiṃ N; $\sqcup$ hāyo yogī siddhiṃ L • 19d kamaṇḍalukaraḥ] N; kamaṇḍaludharas L 
vyāghracarmāmbaraṃ śāntaṃ raudraṃ vratam idaṃ śubham sunișțhasya bhavet șạ̣bhir mmāsaị̣ siddhir ihottamā $\quad 49.15$ madhyā māsaiś caturbhiś ca kṣudrā māsais tribhir bhavet vratānām pravaram raudram tatsiddhau sakalo bhavet $\quad 49.16$ kāryaṃ mantravrataṃ siddhyai sādhakenānurūpakam

13c saśalyas tumbako] em.; saśalyatumbako $\mathrm{N}$; saśalāstambhako $\mathrm{E}_{D} \cdot 14 \mathrm{c}$ śuddha ${ }^{\circ}$ ] N; śuddhaṃ $\mathrm{E}_{D} \bullet 14 \mathrm{~d}$ tṛlocanakṛtādaram] N; trilocanakṛtodaram $\mathrm{E}_{D} \bullet 15$ b raudraṃ] N; raudra ${ }^{\circ}$ $\mathrm{E}_{D} \cdot 15 \mathrm{~cd}$ sunișțhasya bhavet șaḍbhir mmāsaih siddhir ihottamā] N; kanișțhasya bhavec chuddhir māsaị ṣaḍbhir ihottamā $\mathrm{E}_{D} \quad \bullet 16 \mathrm{ab}$ caturbhiś ca kṣudrā māsais] $\mathrm{E}_{D}$; caturbhi syāt kṣudra māsai $\mathrm{N} \quad \bullet 16 \mathrm{c}$ vratānām pravaraṃ] $\mathrm{N}$; vratamapravaraṃ $\mathrm{E}_{D} \quad \bullet 16 \mathrm{~d}$ sakalo bhavet] N; sakaḷam punaḥ $\mathrm{E}_{D} \bullet 17$ a kāryaṃ mantravrataṃ] $\mathrm{E}_{D}$; kāryamantravrata $\mathrm{N} \bullet 17 \mathrm{~b}$ sādhakenānurūpakam] $\mathrm{N}$; sādhakair nānurūpataḥ $\mathrm{E}_{D}$

Alternatively, [instead of a kamandalu,] it may be a gourd with a shaft. Having made this [ready], he should practise his observance. (13cd) This is the auspicious Raudra-vrata: imposing with a chignon of matted locks, marked by a trident and khatvāniga, equipped with a clean half skull, awe-inspiring with a third eye, clothed in the skin of a tiger, peaceful. $(14-15 \mathrm{~b})$

For one firm [in this observance], the highest siddhi will arise in six months; middling [powers] in four months; the lowest [powers] will arise in three months. $(15 \mathrm{c}-16 \mathrm{~b})$

The highest of the observances is the Raudra[-vrata]. On accomplishing that, one becomes [equal to] the Sakala [form of Śiva]. (16cd)

For attaining siddhi, the sädhaka should perform a mantra-observance that is appropriate [to the mantra in question].$^{13}(17 \mathrm{ab})$

What we see here, it seems to me, is a reflection of the old notion that cary $\bar{a}$ refers to vratacary $\bar{a}$, "the performance of a vrata," where vrata is a timed religious observance that typically involves adopting an unusual diet (not mentioned here), an unusual style of dress (often with accoutrements of the cremation ground, in this case the khațvāinga), and unusual behaviour (sexual transgressions, mortuary obsessions, or, as here, ascetic detachment). This observance is furthermore a preparation for the attainment of magical powers through the use of a mantra.

This is, I think, in essence, the same as what is meant by the term vrata in all early tantric literature. It explains therefore how vratacary $\bar{a}$, "the performance

13 Or perhaps "appropriate [to the desired siddhi]." 
of such a vrata," and therefore sometimes also caryā have come to be used interchangeably with vrata. ${ }^{14}$ But the term carya evidently began to expand and then slip in meaning as the Mantramārga expanded to include not just sādhakas (who seem to be the only audience of the Niśvāsatattvasaṃitāa ${ }^{15}$ ), but also other categories of initiates. We can see that this slippage has in fact already taken place by the time of the Kirana, for that work begins its thirty-first chapter with an announcement that the next topic to be taught will be carya and yet, as we have just seen above, does not deal with the vratacaryā of the Sādhaka until chapter 49, which follows eighteen chapters later.

Here is the beginning of chapter 31 , in which the topic called cary $\bar{a}$ is first introduced in such a way as to suggest that the primary meaning has now become something like regular enjoined "comportment."

garuḍa uvāca-

samayisutayor deva kā vịttis tu dine dine

evaṃ mayi samācakṣva caryā me noditā purā $\quad 31.1$

1a samayisutayor] $\mathrm{N}$ (unmetrical); samayīputrayor $\mathrm{E}_{D} \bullet$ • b vṛttis tu] $\mathrm{E}_{D}$; vṛtyatra $\mathrm{N}$ ・1c mayi] conj.; mayā $\mathrm{N}$; sarvaṃ $\mathrm{E}_{D}$

\section{Garuḍa spoke:}

What are the day-to-day activities of the neophyte and the putraka?

Tell me this. You have not taught me the [regular rules of] behaviour (caryā) before. (1)

No such clear evidence can be found of this broadening of the meaning of the word caryā in another post-Niśvāsa but pre-tenth-century Saiddhāntika scripture for which we have an early Nepalese palm-leaf witness, this time apparently of the ninth-century, namely the Sarvajñannottaratantra. ${ }^{16}$ That work gives

14 As for caryāvrata, which, as we have seen above, Wedemeyer considers to be synonymous with vratacaryā, I suspect that it rather means "one of the timed religious observances belonging to [the body of activities that can collectively be called] [vrata-]caryā." No doubt there is, in certain contexts, little difference between saying this and saying "the performance of timed religious observances" (vratacarya $)$.

15 For the absence of initiates who are not sädhakas from the religious teachings of the Niś$v \bar{a} s a$, see Goodall, Sanderson, Isaacson et al. 2015, $47 \mathrm{ff}$.

16 In case it should be supposed that the work's structure is itself evidence of a shift in meaning of the term caryā, I should mention that, although Aghoraśiva's commentary divides it 
us an account of another sort of vrata that will be useful to us in the discussion below, in this case somewhat more detailed, but involving no transgression of brahmanical rules about purity and sexual behaviour.

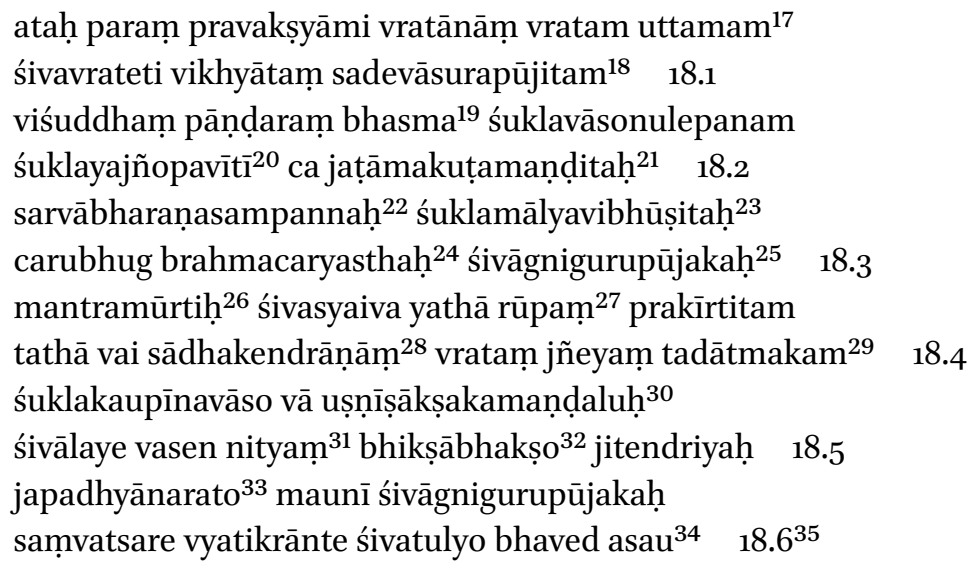

into four $p \bar{a} d a$ s, including a caryāpa $\bar{a} d a$, it was clearly not originally so divided: see Goodall 1998, lix-lxi.

17 vratam uttamam] NL; uttamam vratam M

18 śivavrateti vikhyātaṃ sadevāsura $\left.{ }^{\circ}\right] \mathrm{N}$; śivavratam iti khyātaṃ sarvodāsura ${ }^{\circ} \mathrm{M}$; śivavratam iti khyātạ̣ sarvadā sura ${ }^{\circ} \mathrm{L}$

19 pāṇụaram bhasma] N; pāṇụuraṃ bhasma M; pāṇụaraṃ janma L

20 śukla $\left.{ }^{\circ}\right] \mathrm{NL}$; $\mathrm{M}$

21 'omaṇititah] ML; ${ }^{\circ}$ maṇ ḍitam N

22 'sampannah] $\mathrm{M}$; ${ }^{\circ}$ sampanna ${ }^{\circ} \mathrm{NL}$

$23{ }^{\circ}$ mālyavibhūṣitaḥ] $\mathrm{N} ;{ }^{\circ}$ mālāvibhūṣitah $\mathrm{M}$; ${ }^{\circ}$ mālāvibhūṣitaiḥ L

24 carubhug brahmacaryasthah] $\mathrm{M}$; carabhug brahmacaryastho $\mathrm{N}$; carubhūt brahmacaryasya L

$25 \quad{ }^{\circ}$ pūjakah] NM; ${ }^{\circ}$ pūjitah L

$26{ }^{\circ}$ mūrtih] $\mathrm{M} ;{ }^{\circ}{ }^{\circ} \bar{u}_{\text {rti }}{ }^{\circ} \mathrm{NL}$

27 rūpaṃ] NM; pūrvaṃ L

28 sādhakendrāṇāṃ] NM; sādhakaindrāṇā L

29 vrataṃ jñeyaṃ tadātmakam] NM; vrata jñeyaṃ tathātmakam L

30 śuklakaupīnavāso vā uṣṇiṣākṣakamaṇḍaluh] NM; śuklakaubī(pī)navāsaṃ va uṣnīṣākṣata(ka)maṇ̣alum L

31 vasennityam] $\mathrm{N}$; vasannityam ML

32 bhikșāo] ML; bhikșa ${ }^{\circ} \mathrm{N}$

$33 \mathrm{japa}^{\circ}$ ] NM; śiva ${ }^{\circ} \mathrm{L}$

34 bhaved asau] conj.; bhavedasauditi N; bhaved iti ML

35 Here there is a flourish marking a chapter-break in N, and in the Southern sources there is a chapter-colophon: iti śrīmatsarvajñānottare śivavratapațalo 'șțādaśah M; iti sarvajñānottare kriyāpāde śivavrataprakaraṇam L 
ataḥ paraṃ pravakșyāmi lakṣaṇam ${ }^{36}$ tu śivālaye sthāpanam caiva lingasya yasmin sarvaṃ pratișțitam ${ }^{37}$ 19.1 brahmādyā devatāḥ sarvā lingam āśritya saṃsthitāḥ ${ }^{38}$ tasmād vai sthāpayel lingaṃ ${ }^{39}$ śāstradṛștẹna karmaṇā $\quad 19.2$ cīrṇavidyāvrato ${ }^{40}$ yogī gurudevāgnipūjakaḥ ${ }^{41}$

Next, I shall teach the best observance among observances, which is known as the Śiva-vrata and which is revered by asuras and gods alike. (18.1)

Pure pale ash [should be used, and] white dress and unguents; he should wear a white sacred thread and be adorned by a chignon of matted locks. (18.2)

He should be equipped with all [suitable] ornaments, [and] adorned with white garlands; he should consume [only the pure ritual grueloffering known as] caru; he should observe the chaste conduct of a student; he should venerate Śiva, the fire and his guru. (18.3)

He should be mantra-bodied; ${ }^{42}$ the appearance (rüpam) of excellent sädhakas [who follow this observance] is to be the same as that of Siva: the observance must be understood as consisting in this. (18.4) Alternatively, he may wear [just] a white loin-cloth, [and bear] a turban, rosary and spouted water-pot. (18.5 ab)

He should dwell constantly in a temple of Śiva, eating alms, controlling his senses, devoted to recitation and meditation, maintaining silence, venerating Śiva, the fire and his guru. When a year has passed, he will become equal to Śiva. $\left(18.5^{c}-6\right)$

Next, I shall teach the characteristics of a temple of Siva, as well as [how to perform] the installation of the linga, in which the universe is [itself] 'installed.' (19.1)

36 lakṣaṇaṃ] NMT; lakṣmaṇaṃ L

37 sarvaṃ pratișțhitam] M; sarvvapratișțhitam N; sarvapratișțhitah TL

38 devatāḥ sarvā lingam āśritya saṃsthitāḥ] em.; devatā sarvā lingam āśṛtya saṃsthitā N; devatāḥ sarve lingam āśritya saṃshitaḥ $\mathrm{M}$; devatā sarve lingam aśritya saṃsthitāh T; devatās sarve lingam āśritya saṃsthitāh $\mathrm{L}$ sthāpayel lingaṃ śāstra ${ }^{\circ}$ MTL; sthāpaye lingaṃ śastra ${ }^{\circ} \mathrm{N}$ cīnnavidyāvrato yogī] N; cīnno vidyāvrato yena M; ciṇyāṃ vidyāvratā yoga T; ciṇyāṃ vidyāvrato yogī L. Cf., e.g., Mohacụ̄̂tottara (N GM PP A 182/2, f. 2r): cīrnavidyāvrato mantrī jñānavān susamāhitah.

$41 \quad{ }^{\circ}$ püjakaḥ] NML; ${ }^{\circ}$ pūrvakah T

42 I assume that this means that the mantras of Śiva should be installed upon his body. 
All the gods, beginning with Brahmā, reside in the linga; therefore a yogin who venerates his guru, God and the fire and who has performed his vidyāvrata should install the linga, following the procedure taught in scripture. $(19.2-3 \mathrm{~b})$

We shall return below to the use of the term vidyāvrata, which I have not translated here. First we may observe that these passages of the Kirana and Sarvajñanottara might appear to confirm Wedemeyer's observation that the vratas in early Śaiva works were observances in which the sādhaka imitated God (2013, 165).

The early Śaiva Tantric paradigm for the transgressive vrata, then, was one of imitatio dei-mimicking the activity of the god in the interest of eliding the (presumably mistaken) sense of a gulf between him and the devotee. In none of these rites is there mention of transcendence of conceptuality or attainment of any epistemic nonduality—the concern seems entirely to be one of nonduality in the sense of union with the god Śiva.

Imitation of forms of god, whether pure or transgressive, seems indeed to be typical of vratas in early Śaiva sources, but it is not the invariable rule, as the Niśvāsa demonstrates. ${ }^{43}$ Several vratas are described in the course of the work, but there is one passage in which a set of nine is concisely described together, namely in chapter 3 of the Guhyasütra. A brief summary of the contents of that chapter will help to contextualise that description, showing that it is part of a chapter devoted to 1) preparations for magical pursuits, and 2) magical procedures:

43 Nemec also (2014, 273) expresses doubt about this point of Wedemeyer's:

I am, in a word, not convinced that the many transgressive practices in the "early period" of Śaiva tantra, defined as "pre-tenth century" (165), involve a practice of imitatio dei, "of union with the god Śiva," to the exclusion of "transcendence of conceptuality or attainment of any epistemic nonduality" (ibid.).

As to what states of consciousness such non-imitative observances might or might not be intended to achieve, the text gives us no direct information; we can only say that it does elsewhere describe practices whose purpose is said to be transcending duality, for example in yogic meditations described in Uttarasūtra 5.42-43 and Nayasūtra $4.55 \mathrm{ff}$., and that a non-dualist cosmogony is sketched out in Uttarasūtra 1.13. 


\section{Summary of Guhyasūtra 3}

\section{Preparations for magical pursuits}

3.1-2 Having set up the God of gods in a suitable place, one may employ a ritual assistant (uttarasādhaka) for attaining the highest siddhi.

3.3-6 Qualifications of the uttarasādhaka.

3.7-11 Construction of a special dwelling for the pursuit of siddhi.

$3.12 c-16$ Alternative: a suitable cave or empty temple. One should live

from vegetables or begging or from roots, and perform fasts (cān-

drāyaṇa, etc.)

3.17-22 Prognostication of success in siddhi by consulting SvAPNA-

MĀṆAVAKA by calling him to appear in one's sleep.

3.22-23 Prognostication by consulting Amog hamantrarāja.

3.24-27 Catoptromantic prognostication ( prasinna $)$ using virginal chil-

dren and the mantra of CAṆīi

3.28-29 japa using the akșamāla [in order to prepare it].

$3 \cdot 31-43^{b}$ vratas.

\section{Magical procedures}

$3.43 \mathrm{c}-112$ sādhanas for attaining various siddhis.

Having underlined the context, we may now turn to the vratas given in this chapter, followed, by way of example, by one magical procedure. We may note that all of these observances transgress social norms to some degree, but that none unambiguously involves imitatio dei:

siddhi-m-aiśvaryayogyas ${ }^{44}$ tu na ca hiṃsanti hinsakāh $\quad 3.29$

siddhavidyāvratastho hi jape ${ }^{45}$ ca vratam ārabhet

go mātā ca pitā bhrātā atithir mitra brāhmaṇạ̣ $\quad 3.30$

hato me pāpa[[(cāre)]] ṇa ${ }^{46}$ caren (1) Mithyāvratam vratī

<<karasthena kapā >>lena ${ }^{47}$ khațvāngī bhasmaguṇțhitạ̣ $\quad 3.31$

śmaśāne carate rātrau (2) Śmaśānavrata ucyate

44 'yogyas tu] NW; ${ }^{\circ}$ yogye tu K

45 jape] NW; japam $\mathrm{K}$

46 pāpa[[(cāre)]]ṇa] K; yāpa XXṇa N; yāpa Xreṇa W; pāpakāreṇa conj. Sanderson (2006, 209)

47 karasthena kapālena] conj. Sanderson; ---lena NW; பna K 
nṛtyate gāyate caiva unmatto hasate bruvan ${ }^{48} \quad 3 \cdot 3^{2}$

bhasmāñī cīravāsaś ca (3) Gạ̣avratam idạ̣ smṛtam

japayukto bhaikṣabhujo loșțusāyī jitendriyah $\quad 3.33$

dhyānasaṃyamayuktaś ca (4) Loṣțukavratam ācaret

rikṣavyāghrasamā[[kīrṇe] $]^{49}<<$ vane siṃ >> hasamākule 3.34

jitanidrāśano ${ }^{50}$ jāpī (5) Kāṣṭhavratam idañ caret

gāyate nṛtyate jāpī strīrūpī valayabhūṣitaḥ ${ }^{51} \quad 3 \cdot 35$

śūrppakandukaveṇībhiś (6) Citravratam idañ caret

śastrapāṇir dayāyukta-m-aṭe trāteva ${ }^{52}$ †jatavān† $\quad 3.36$

japadhyānārccanirato (7) Vīravratam idañ caret

varṣaśîtātapair ddehan tāpayed dhi su--- $3 \cdot 37^{53}$

japadhyānarataś caiva (8) Mahāvratas sa ucyate

ratisaṃbhogakuśalāṃ rūpayauvanaśālinīm $\quad 3 \cdot 38$

ìdrósīm striyam āsādya niruddhendriyagocarah

cumbanālinganan் kuryāl lingaṃ sthāpya bhagopari

japadhyānaparo bhūtvā (9) Asidhāravratañ caret

yadi kāmavaśaṃ gacchet patate ${ }^{54}$ narake dhruvam $\quad 3.40$

navātmakañ japel lakșaṃ ((tasya)) ---ddhaye $\mathrm{e}^{55}$

abdạ̣ șaṇmāsamātram vā yaś cared vratam uttamam

tasya siddhị prajāyeta adhamā madhyamottamāa ${ }^{56}$

vratasthạ̣ ${ }^{57}$ pañcalakṣāṇi punar japtvā tu siddhyate $\quad 3.42$

sarve mantrāś ca siddhyante īpsitañ ca phalam bhavet

\section{[A spell for travelling great distances:]}

oṃ namo vāyupathacāriṇe amitagatiparākramāya vimale kulu $2^{58}$

thatha 3.43

48 bruvan] NW; dhruvam K

49 'kīṇe] conj.; ${ }^{\circ}$ kīrṇa ${ }^{\circ} \mathrm{K}$; ${ }^{\circ} \mathrm{kā}---\mathrm{N}$; ${ }^{\circ} \mathrm{kā} \sqcup \mathrm{W}$

$5^{\circ}{ }^{\circ}$ drāśano] N; drāmano K; ${ }^{\circ}$ drāsano W

51 valayabhūṣitah] conj. (unmetrical); valabhūṣitah NKW

52 m-ațe trāteva] conj.; mațhe trā--- N; mațhatrā $\sqcup$ ca K; mațhe trā $\sqcup \mathrm{W}$

53 'tāpayeddhi su] N; ' tāpaye $\sqcup \mathrm{K}$; ${ }^{\circ}$ tāpayedvi $\sqcup \mathrm{W}$

$54{ }^{\circ}$ vaśam gacchet patate] conj.; ${ }^{\circ}$ vaśam cche patate $\mathrm{N} ;{ }^{\circ}$ vratam gacchet patate $\mathrm{K} ;{ }^{\circ}$ vaśam chai Xpatate W

55 lakșam tasya ---ddhaye] em.; lakșa---ddhaye N; lakșa $\sqcup$ dvaye K; lakșam tasya $\sqcup$ dvaye W; lakșam tasya mantrasya siddhaye conj. Diwakar Acharya; lakșaṃ saṃvatsaradvaye conj. Diwakar Acharya

$5^{6} \quad{ }^{\circ}$ mottamā] K; ${ }^{\circ}$ mottamāḥ NW

57 vratasthah] K; vratastha NW

58 kulu 2] conj. Sanderson; kula---2 N; kulam $2 \mathrm{~K}$; kula $2 \mathrm{~W}$ 
śilā suvarṇadhātuñ ca $((\mathrm{ka}))$--- tam

varāhavaśasampișțạ̣ ${ }^{59}$ sahasraparimantritam $\quad 3.44$

navātmakam punar japtvā pādau caiva pralepaye[[t]]

gacchate so 'pariśrānto yojanānāṃ śatadvayam $\quad 3.45$

[Once the rosary has been thus prepared, he becomes] ready for siddhis and power. (29cd)

Dangerous creatures do not harm one who has [first] accomplished an observance [that qualifies one] for [using] Spells: he should begin an observance by means of recitation (jape[= japena $]$ ). ${ }^{60}$ (3oab)

The one engaged in observance should practise the False Observance (mithyāvrata) [by wandering about proclaiming]: "I have committed bad deeds: I have killed a cow, mother, father, brother, a guest, friend, brahmin!" (3oc-31b)

[If] one wanders in the cremation-ground at night, with a skull in one's hand and a khațvaniga, covered in ashes, that is called the cremationground observance (śmaśānavrata). (31c-32b)

If one dances, sings, laughs and talks madly, with the body smeared in ashes and wearing rags, this is called the Ganavrata. $(32 \mathrm{c}-33 \mathrm{~b})$

One performs the Clod-of-Earth Observance (loștukavratam) by being engaged in recitation, feeding on alms, sleeping on the earth, with senses controlled, engaged in meditation and restraint. (33c$34 b)$

One may perform the Block-of-Wood Observance (kāșthavratam) in a forest full of bears, tigers and lions, conquering the urges to sleep and eat, [constantly] reciting. ( $34 \mathrm{c}-35 \mathrm{~b})$

If one takes on the appearance of a woman and sings and dances, adorned with bracelets, with a winnowing fan, ball and plait, one observes the Colourful Observance (citravratam). $\left(35^{\mathrm{c}-36 \mathrm{~b}}\right)$

With a weapon in hand, full of compassion, if one wanders like a saviour of creatures (?) ${ }^{61}$ focussed upon recitation, meditation and worship, one performs the Warrior Observance (viravratam). $(36 c-37 b)$

59 varāhavaśasampișțaṃ] conj.; varāhava+sa+sampișța ${ }^{\circ} \mathrm{N}$; varāhavamasaṃpișțam K; varāhavaśasampișța $\mathrm{W}$

6o This replaces the translation, in which I no longer believe, of $30 a b$ that we offered on p. 285 of Goodall, Sanderson, Isaacson et al. 2015.

61 This tentative translation assumes that jatavān is an error for jantavām, intended as a genitive plural with the sense of jantūnām! 
If one torments the body with rain, cold and heat, ..., devoted to recitation and meditation, this is called the Great Observance (mahāvratah). (37c-38b)

A woman skilled in the pleasures of love-making, endowed with beauty and youth; such a woman one should procure, holding one's senses back from the objects of the senses, and one should kiss and embrace [her], placing the penis upon her sex while remaining focussed upon recitation and meditation-one performs [thus] the Sword-Blade Observance (asidhārāvratam). If one should succumb to the control of desire, then one certainly falls into hell. $(38 \mathrm{c}-40)$

One should recite the NAVĀTMAN one lakh times ... for [si]ddhi: one who [thus] observes such an excellent observance for a year or just six months attains lowest, middling or best siddhi. But if, while observing such a vrata, someone recites five lakh times, then [that mantra] succeeds [for him] (siddhyate), and all mantras succeed for him and he attains the fruits he desires. $(41-43 \mathrm{~b})$

[Using the mantra] OṂ NAMO VĀYUPATHACĀRIṆE AMITAGATIPARĀKRAMĀYA VIMALE KULU KULU SVĀHĀ, [and taking] arsenic, gold [and?] a mineral, ..., ground up with pig fat/marrow, over which one has recited [the NAVĀTMAN] 1000 times, he should smear [the mixture] on his feet/legs, while once again reciting the NAVĀTMAN: he will travel 200 yojanās unwearied! (43c-45)

Right at the beginning of the above-quoted passage, we find a further attestation of the term vidyāvrata, and this time, rather than prevaricating further, I have proposed translating it as "an observance [that qualifies one] for [using] Spells." There are other passages that can and will be adduced in support of this, but I think that it should already be becoming clear from this passage of the Guhyasütra and from the passage quoted just before from the Sarvajñannottara that the different particular vratas that are performed serve to prepare the performer for some subsequent religious activity that involves the use of the mantra or vidya . In the case of the Guhyasütra, it is the pursuit of siddhi for which the sādhaka is prepared; in the case of the Sarvajñānottara, the individual is prepared for the performance of the installation (pratisțtha $)$ of a linga. From the beginning of chapter 10 of the kriyāpa da, we learn that it is also an essential to the consecration of an àcārya in the Matangapārameśvara:

catuṣpādārthakuśalaṃ mahotsāhaṃ hy aninditam $\quad 10.2$ șațpadārthapranītārthaṃ sarvabhūtahite ratam gurus tam abhiṣiñcet tu cīrṇavidyāvratạ̣ naram $\quad 10.3$ 
Rāmakaṇtha: atha kiṃ tad vidyāvratam yat tena cīrnam ity ucyate:

vidyāśaktir ihopāttā japtavyā prāk chivālaye saṃniyamyendriyagrāmam abdam ekaṃ śuciṣmatā $\quad 10.4$ nityaṃ carubhujā bhūmyāṃ kuśaprastaraśāyinā pūjāgnibhavane yuktacetasā bhāvitātmanā 10.5

\section{Rāmakaṇțha: [vidyāśaktiḥ] vyomaryāpilakșaṇa ${ }^{62}$}

The guru should consecrate [as an ācārya] a man who is skilled in what is taught in all four pādas, who has great energy, who is beyond reproach, who expounds the meaning of the teachings [encapsulated] in the six topics [of this scripture], who is devoted to the welfare of all beings, who has performed the observance for [the propitiation of his] mantra.

Rāmakanțha: Now if you ask what this vidyāvrata is which he must have observed, this is what the text teaches:

The power of the vidya that is mentioned here [in this compound $v i d y \bar{a}-$ vrata] is first to be recited for a year in a temple to Siva, while exercising control of the senses, maintaining purity, eating daily [only the sacrificial gruel known as] caru, sleeping on the ground in the room reserved for $p \bar{u} j \bar{a}$ and fire[-sacrifice] on a spread of kuśa-grass, with his mind engaged [in meditation], focussed.

Rāmakaṇtha: It [viz. the power of the vidyā] is the VYOMAVYĀPIN.

Once this preparation, taking the form of the observance of one among a variety of possible vratas (but ideally one suitable to the mantra to be put to use, as seems already to be implied in Kirana 49.17ab above, and as we shall see confirmed below), is complete, the observer can be called cirnavidyāvratah (as here and in Sarvajñānottara 19.3a) or siddhavidyāvratasthah (as in Guhyasūtra $3 \cdot 30 a)$.

If we make such an assumption, then we can see how the expressions vratacaryā and vidyāvrata might be regarded as interchangeable in some con-

62 From Rāmakantha's commentary, only the avataranika and the commentary to 10.4-6 are quoted here (not the remarks on $10.2 \mathrm{c}-3$ ). The pratika in square brackets is supplied by the editor. 
texts, ${ }^{63}$ even though they are not actually synonymous. It also becomes clear how it is that vidya vrata can be characterised as preparatory mantra-propitiation and therefore equivalent to what may also be called puraścarana. Sanderson characterises it in such a way when referring to the account of the Bhairavācārya in Bāṇa's Harșacarita:

With this account of a pürvasevā, also called puraścaryā or vidyāvratam, i.e. the initial period of ascetic japah etc. to be undertaken after one has received a Mantra, whereby one becomes able to accomplish feats (karmāni) with that Mantra ...64

So if vrata and vratacarya and some other terms may seem to be used interchangeably in some works with vidyāvrata, it is because the principal purpose of the vratas taught in the early Mantramārga seems to be to propitiate mantras prior to further religious activities involving those mantras, rendering those who complete such observances describable by such terms as cirnavidyāvrata, siddhavidyāvratastha, vidyāvratasnāta and so forth. ${ }^{65}$ Various observances can, in other words, be observed in order to become one "who has completed the observance [required for the propitiation] of a vidyā."

This discussion might seem to suggest that in finding the original meaning of the expression vidya $v$ rata we believe that we have found its immutable semantic core, but that is not really what I intend to say. Of course the term vidyāvrata may have gone on to evolve and be used in contexts that suggest that one might elsewhere also or instead render it as "knowledge observance" or "consort observance" (Wedemeyer 2013, 136) or, as we shall see below, "observance relating to a vidyāngamantra." ${ }^{66}$ Furthermore, one might argue that we have in

63 Cf. Wedemeyer 2013, 159: "It is worth noting that the Tantrasadbhāva/Kubjikämata and the Siddhayogeśvarimata clearly take the terms vidyāvrata and vratacaryā to be synonymous."

64 Sanderson 2001, 13, note 11. Wedemeyer quotes from this definition (2013, 255, note 96), but in a manner that suggests that he was oddly not convinced by it, or not convinced that the same kind of vidyāvrata was being alluded to by Sanderson:

Sanderson ("History", 13n11) also describes a very different rite [scil. from that referred to in Vịnāsikhatantra 180?] when he speaks of vidyāvrata as an "initial period of ascetic

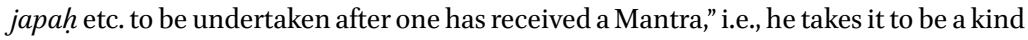
of pūrvasevā or puraścaryā.

65 Another purpose of performing vratas in the early Mantramārga is of course expiation: see, for example, Guhyasūtra 9.10a, Siddhayogeśvarimata 10.3c, both quoted below, and Hṛdayaśiva's Prāyaścittasamuccaya passim (appendix to Sathyanarayanan 2015).

66 We do not aim, however, to examine here all later passages in which the meaning of vidyāvrata is arguably stretched. One such passage is a sequence of verses discussing the term that has been borrowed from the Tantrasadbhāva into the Kubjikāmata: that dis- 
any case not started from its point of origin, for the term has presumably been drawn from or at least coloured by the brahmanical expression vidyāvratasnäta that is common from the Grhyasütras onwards and that we find, for instance, in Manusmrti 4.31:

vedavidyāvratasnātān śrotriyān grhamedhinaḥ

püjayed dhavyakavyena viparïtāmśs ca varjayet

Olivelle $\left(2005,125^{-126)}\right.$ translates:

At rites for gods and ancestors, he should honor individuals who have bathed after completing the Vedas, vedic learning, or vedic vows, who are vedic scholars, or who are householders, but avoid individuals different from these. ${ }^{67}$

It seems to me very likely that the use of vidyāvrata in the Mantramārga-and a fortiori of vidyāvratasnāta (Siddhayogeśvarīmata 10.20 and Svāyambhuvasūtrasangraha 21.35) — should have been influenced by earlier brahmanical usage such as we see in the Grhyasütras and in the Manusmrti. Nonetheless, in the

cussion begins with Bhairava saying (Tantrasadbhāva 4.2ab = Kubjikāmata 25.30ab): śrṇu devi pravakșyāmi vidyāyā vratam uttamam, "Listen, O goddess: I shall teach the excellent observance of/for vidyā."

67 Olivelle also adds a note that explains that there is doubt about the term $(2005,270)$ :

$[\mathrm{M}]$ ost commentators take vedavidyā $v$ rata as three separate categories. The first refer to those who have only learned the Veda by heart; the second to those who have mastered its meaning; and the third to those who have completed the vows associated with vedic study, such as living with the teacher for a certain number of years, even if they have not mastered the Veda.

This interpretation is not wholly consistent with what we find earlier in Gṛhyasütra literature. In Jaiminigrhyasūtra 1.19 (p. 18), for instance, we read:

trayaḥ snātakā bhavantīti ha smāhārunir gautamo vidyāsnātako vratasnātako vidyāvratasnātaka iti teșām uttamaḥ śreșthas tulyau pūrvau.

Caland $(1922,32)$ translates:

According to Ârunii Gautama there are three kinds of Snātakas: the Snātaka by knowledge, the Snātaka by the completion of his observances, and the Snātaka by knowledge and by the completion of his observances. Of these the last ranks foremost, the first two are equal (to each-other).

Cf. Pāraskaragrhyasūtra (kāṇ̣̂ 2, kaṇdikā 5 , sentences 32-35, p. 220):

trayaḥ snātakā bhavanti: vidyāsnātako vratasnātako vidyāvratasnātaka iti 32 samāpya vedam asamāpya vratam yaḥ samāvartate, sa vidyāsnātakah 33 samāpya vratam asamāpya vedam yạ samāvartate, sa vratasnātakaḥ 34 ubhayam samāpya yạ̣ samāvartate, sa vidyāvratasnātaka iti 35 
Niśvāsa certainly, and probably throughout the early Mantramārga, the use of vidyāvrata to mean "observance for [the propitiation of] a mantra" seems to be the norm. As Sanderson has observed in the note of his that we have just quoted, vidyāvrata seems indeed to be used in the same way as pürvasevā in the Niśvāsa. Many short paragraphs of prose in the grimoires (kalpa) that we find in the Guhyasūtra sketch out the essential features of particular observances, and these paragraphs are very often concluded with a succinct statement of the magical powers that can be won by following them (the power to fly, for example, or to disappear); but sometimes we find instead the assertion that the observance fulfils the requirements of purrvaseva $(10.27,10.99,14.26)$ or puraścaraña (14.24) or, as here in Guhyasūtra 10.91, the requirements of the vidyāvrata:

devạ̣ püjyāgnau juhuyād audumbarasamidhānām tryaktānām sahas-

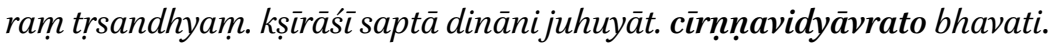

Having worshipped the Lord, he should oblate into the fire at the three junctures of the day a thousand pieces of Udumbara-wood smeared with the three [sweet substances]. Consuming [only] milk, he should make oblations [in this manner] for seven days. He will become one who has accomplished the vidyāvrata.

Before I wrap up the discussion, it should be mentioned that a different hypothesis as to the meaning of vidyā rrata was advanced some years ago, when many of the above-cited passages had not yet come to light, by Judit Törzsök when translating chapter 10 of the Siddhayogeśvarimata. We quote here the beginning of the chapter (without the apparatus) from Törzsök's 1999 edition:

devy uvāca

mayā deva purā pṛștạ̣ vratayāgavivarjitam

siddhayogeśvarīṇāṃ tu mataṃ mantraprasādhakam $\quad 1$

kiṃ tu deva pratijñātaṃ siddhir vidyāngasaṃsthitā tasmāt teșu samāsena vratacaryāṃ bravīhi me $\quad 2$ bhairava uvāca ādau tu sarvasiddhyarthaṃ sarvavighnavināśanam sarvapāpāpanodārthaṃ vidyāvratam samārabhet 3 sādhakah sādhakī vātha mantratadgatacetasah yāgaṃ kṛtvā vidhānena vratacaryāṃ samācaret 4 bhasmalepitasarvāngo maunī śuklāmbaraḥ sudhịh sitayajñopavìtaś ca akāmo niyame sthitạ $\quad 5$ 
Here is Törzsök's translation $\left(1999^{*}, 143\right)$ :

The Goddess spoke

I have previously asked you about the Doctrine of the Yoginiss (Siddhayogeśvarimata), O God, which helps to make mantras effective (mantraprasādhakam) without any observances or worship. (1)

However, you have asserted, O God, that success depends on the ancillary mantras; therefore, tell me briefly about how to practise the observance[s] associated with them (teșu). (2)

Bhairava spoke

First [before any other practice to attain a specific supernatural power], for all kinds of supernatural powers, [and] for expiatory purposes, one has to start the observance of the [ancillary] mantras, which destroys all obstacles. (3)

The male or female practitioner, with his/her mind focused on the mantra, should perform worship according to prescriptions and then undertake the vow (vratacaryām). (4)

[In the first of these] all his limbs covered with ashes, the practitioner is to observe silence and should wear a white garment; he should be of good understanding. He must have a white sacred thread, he should be free from desire and established in self-restraint. (5)

Now the reason that Törzsök translates vidyāvrata with "the observance of the [ancillary] mantras" is that each of the vratas in the chapter is specific to the cultivation of a particular auxiliary mantra - the first one, given above in verse 5 , must, by elimination, be an observance for the HRDAYA-mantraand those auxiliary mantras belong to a set known in this work and in others as the vidyāingamantras. ${ }^{68}$ It was therefore reasonable for her to assume that vidyāvrata was short for vidyāingavrata, for she had no evidence to suggest otherwise, and she had parallel evidence that seemed to reinforce this hypothesis, namely the testimony of Svāyambhuvasūtrasaingraha 21 (from which Törzsök quotes, citing Alexis Sanderson's collation, in her notes on p. 78).

That passage again gives a series of vratas, which are, by the way, again not instances of imitatio dei, and which are again specific to the vidyāingamantras; so it is wholly understandable that this seemed to Törzsök in 1999 to confirm

68 For these mantras and their individual names, see Brunner 1986 and, more recently, Goodall 2004, 222-223. 
the notion that the element vidya in the collocation vidyāvrata must refer to the vidyängamantras. I think, however, that it will now be clear that chapter 21 of the Svāyambhuvasūtrasangraha might in fact be interpreted equally well internally if we assume that vidyāvrata is used instead to mean "observance for [propitiation of] a mantra" and that, given the other attestations of the term that we now know about in, for instance, the Guhyasütra, the Matanga, and the Sarvajñannottara, it actually makes better sense to assume this broader interpretation in this passage too.

There is somewhat better evidence for pinpointing the place of the Svāyambhuvasūtrasangraha in a relative chronology of Saiddhāntika writings than there is for most other pre-tenth-century Siddhāntatantras, for in terms of both doctrinal and social developments, it seems later than the sütras of the Niśvāsatattvasaṃhitā (see Goodall, Sanderson, Isaacson et al. 2015, 41-44, 47-50, 58 ), and yet it cannot be later than Sadyojyotih, who has written a commentary upon it and who, Sanderson argues (2006b, in particular p. 76), lived between c. 675 and $725 \mathrm{AD}$. The edition is not widely accessible, which may be why Wedemeyer did not refer to this passage, and its text almost invariably needs to be corrected against manuscripts, but this particular chapter has just been published anew, in the form in which it appears when quoted by Hṛdayaśiva in his Prāyaścittasamuccaya (see Sathyanarayanan 2015, Appendix chapter 10). ${ }^{69}$

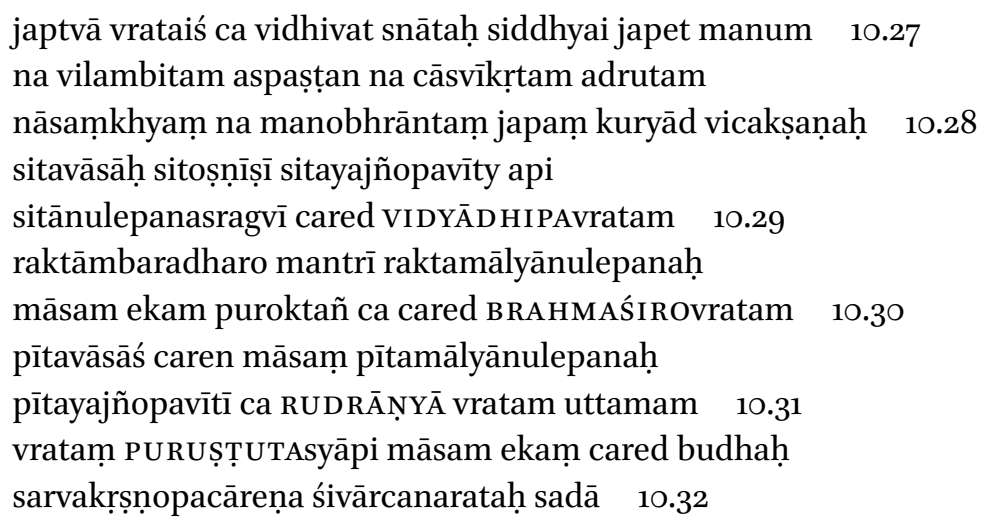

69 In the collation below, $\mathrm{H}$ is the reading of Sathyanarayanan's transcription of the twelfthcentury manuscript transmitting Hṛdayaśiva's work (where this chapter is the tenth); Ed. is of course the Mysore edition of 1937 (where the chapter is the twenty-first), and N marks the readings of the old Nepalese palm-leaf manuscript filmed by the NGMPP on Reel A 3o/6. 
citrāmbaradharo dhīraś citramālyānulepanạ̣

sarvasiddhiparo mantrī caret PĀŚUPATAṂ vratam 10.33

vratavratasamāptau ca kalaśena śivāmbhasā

svamantraparijaptena svātmānam abhiṣecayet 10.34

evaṃ vidyāvratasnātạ̣ sarvatrādhikṛto 'naghạ̣

japen mantram anudvignaḥ svakalpavidhinā tatạ $\quad 10.35$

27c vrataiś] H, Ed.; vrajaiś N • 27d manum] H, Ed.; matam N • 28a na vilambitam] H, Ed.; avilambitam N • 28c manobhrāntaṃ] H; mobhrāntam N (unmetrical); manobhrānta ${ }^{\circ}$

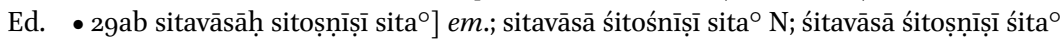
H; sitavāsāḥ sitoṣnīṣaḥ sita ${ }^{\circ}$ Ed. • 29c sitānulepanasragvī] conj.; sitānulepanah sragvī N, Ed.; śitānulepanaḥ sragmī H • 29d vidyādhipa ${ }^{\circ}$ Ed.; vidyādhipaṃ N, H • 3oa raktāo] H, Ed.; rattāo N • 31a pītavāsāś] N, Ed.; pītavāsā H • 31c rudrāṇyā] N, Hac, Ed.; rudrāṇīo Hpc - 32a purușțutasyāpi] N, H; puruhūtasyāpi Ed.pc; purutasyāpi Ed.ac • 33c sarvasiddhiº] N, H; sarvasiddha ${ }^{\circ}$ Ed. • 33 d pāśupatam] N, H; pāśupata ${ }^{\circ}$ Ed. • 34 a vratavratasamāptau ca] Ed.; vrataṃ vratasamāptau ca N; vratavrataṃ samāptau tu $\mathrm{H} ・ 35^{2}$ vidyāvrata ${ }^{\circ}$ ] N, H; vidyāvratah Ed. • 35b sarvatrādhikṛto] N; sarvatrāvikṛto H; sarvato dhikṛto Ed.

Having recited [a particular mantra] along with [the practice of one of the] observances in accordance with the rules, and having bathed [at the end of the observance], one may recite that mantra for attaining supernatural powers. $(27 \mathrm{~cd})$

The skilled practitioner should do his recitation not too slowly, not indistinctly, not without taking [the meaning of what he recites] in, not too fast, not without counting, and not with his thoughts in confusion. (28)

Dressed in white, with a white turban and a white sacred thread and white unguents and garland, he should perform the observance for the VIDYĀDHIPA-mantra. (29)

Dressed in red garments and red garlands and unguents the Mantrin should first perform for one month the stated observance for the BRAHMAŚIRAḤ. (30)

Wearing yellow garments and yellow garlands and unguents and a yellow sacred thread he should perform the excellent observance of RUDRĀṆi for a month. (31)

The competent ritualist (budhah), constantly devoted to the worship of Siva, should perform the observance for PURUȘṬUTA for one month with all accoutrements being black. (32)

The mantrin, intent on attaining all manner of special powers, should perform the observance for the PĀśSPATĀST RA resolutely (dhïrahn) dressed in multi-coloured garments and with multicoloured garlands and unguents. (33) 
And upon the completion of one or another of these observances (vratavratasamāptau), ${ }^{70}$ he should pour upon himself Śiva-water that has been consecrated by recitation of his mantra over it from a pot. (34)

Being thus bathed after the observance [in propitiation] of [his] mantra, invested in the right to [pursue] all [manner of special powers], faultless, he should then recite [his chosen] mantra according to the rules of his hand-book, ${ }^{71}$ without being afraid. (35)

In the above lines, $27 \mathrm{~d}$ and 35 seem to make particularly plain that these vratas are performed by way of pürvasevā, also known as vidyāvrata, as a preliminary to the pursuit of siddhi.

Csaba Kiss, following Judit Törzsök's lead, has also alluded to the link between vidyāngamantras and the name vidyāvrata, but I think it will be clear from what he says below that the evidence that his new edition of parts of the Brahmayamala has recently brought to the discussion again supports rather the broader interpretation, in which the element vidya alludes to any mantra, not just a vidyānigamantra. Below are his remarks $(2015,211)$ on Brahmayāmala $21.4-5$ b, which he constitutes and translates as follows:

ete nava vratā proktā vidyābhede vyavasthitā eteșām tu yathānyāyaṃ yathā caryā bhave tv iha kathayāmi mahādevi tan me nigadatạ̣ śrṇu

These are the nine ascetic observances (vrata), corresponding to [the syllables of] the Vidyā[, Caṇ̣ā Kāpālinī’s nine-syllable mantra]. I shall now teach you how to perform them correctly, O Mahādevī. Listen to me [while I] teach you.

... these observances are in fact called the vidyāvratas in 21.10c, $42 \mathrm{~d}, 47 \mathrm{a}$, $5 \mathrm{~b}, 53 \mathrm{~b}, 75 \mathrm{~d}$ and $102 \mathrm{~d}$; the nine types of observances obviously correspond to the nine syllables of the Navākșaravidyā (OṂ CAṆ̣E KĀPĀLINI SVĀHĀ), taught in BraYā 2; vidyāvratas may also serve, as seen in many tantric texts, as preliminary propitiation, by the use of vidyängamantras, of a mantra to be applied later, or simply for the purpose of gaining

70 The text and interpretation are not certain here. A possible conjectural emendations that suggests itself is vratī vratasamāptau.

71 For this sense, see Tāntrikābhidhānakośa, vol. 2, s.v. kalpa. 
mastery over the Vidyā, similarly to the way it is taught in the Yoginīsamcāra; as Sanderson (2009:134 n. 311) remarks: ...

More closely parallel to these nine observances, as we can now see, are the nine taught in chapter 3 of the Guhyasütra, which are probably each for one of the nine elements of the NAVĀTMAN. So perhaps the association with vidyāngamantras is simply a red herring.

Kiss's reference there to Sanderson 2009, 134, note 311 proves to be another passage in which Sanderson reveals that, although he did not spell out every detail of his assumptions and the evidence upon which he based them, he had in fact already assumed the interpretation for which we have been somewhat long-windedly arguing here, both of vidyāvrata and of its relation to individual named vratas:

The Yoginisamcāra requires anyone who has gone through its initiation ceremony and then received consecration (abhișekah) to adopt one of three forms of ascetic observance in order to gain mastery over the Vidyā (vidyāvratam): the Bhairavavrata, the Cāmuṇ̣āvrata, or the Trișaștikikulavrata, the observance of the sixty-three families [of the Mothers], which it also calls the Kāpālavrata, i.e. the Kāpālika.

So let me reiterate my conclusion: we should probably assume that, even if the expression vidyāvrata was originally drawn from the common brahmanical expression vidyāvratasnāta that we saw in Manusmrti 4.31, and even if it may have been subsequently coloured in some contexts by other associations of the word vidyā (vidyāngamantra, "knowledge," "consort"), the expression vidyāvrata appears throughout the early Mantramārga to be used with the understanding that it refers primarily to an "observance for [the preliminary propitiation of a] mantra." While some works (such as the Saiddhāntika Kiranatantra, and the Sarvajñannottaratantra) appear to mention only one way of fulfilling the requirements of the vidyāvrata, many others (Niśvāsa, Yoginisaṃcāra, Brahmayāmala, Svāyambhuvasūtrasañgraha, Siddhayogeśvarīmata, Tantrasadbhāva, Kubjikāmata) teach several vratas, not all of which are equally transgressive and not all of which involve imitatio dei, as alternative ways of realising the vidyāvrata.

Finally, let me show how this assumption seems to me to throw light even on passages where none of the terms that we have been discussing actually occur. The first few times I read the beginning of chapter 9 of the Guhyasutra, it seemed to begin with a curious non sequitur: the goddess asks a question about how the alphabet, treated as mantra, can be used to bring about supernatural 
power and liberation; Śiva's reply, however, first explains at some length how someone should dress half his body as the goddess and the other half as Śiva. How could this, I asked myself, be an answer to the goddess' question? Was the apparent incoherence of the text here an indication that it had become corrupt?

devy uvāca-

mātṛkāyā bhavet siddhir mmokșañ caiva maheśvara

mātṛ̂āsiddhim ākhyāhi mokșañ caiva yathā bhavet $\quad 9.1$

tatsamutthāś ca ye mantrāḥ kimarthan kathitās tvayā

etat praśnavaraṃ brūhi ((bha))---phalaṃ hi me $\quad 9.2$

ísvara u-

arddhastrīveśadhārī tu arddhena puruṣas tathā

arddhena alakaṃ kuryād arddhenaiva jațādharaḥ $\quad 9 \cdot 3$

tilakārddhena netrārddhe vālikā hy ekakarṇnake

kuṇ̣alaṃ hy ekakarṇne tu śūlan dakṣiṇahastatạ̣ $\quad 9.4$

vāmapārśve ${ }^{72}$ stanañ kuryād vāmārdhe caiva mekhalām

valayaṃ vāmahaste tu vāmapāde tu nūpuraṃ $\quad 9.5$

rucakaṃ dakṣiṇe pāde muñjamālāṃ tathā kațau ${ }^{73}$

kaupīnan dakṣine kuryād vāme strīvastradhāritā $\quad 9.6$

śūrppam vāmakare g̣̣hṇed ardhanārîśvaravrate ${ }^{74}$

etad vratan gụhītvā tu bhikṣāśí tu jitendriyah $\quad 9 \cdot 7$

japahomarato nityam pratigrahavivarjjitah

triṣkālam ${ }^{75}$ arccayed devaṃ triṣkālaṃ snānam ācaret $\quad 9.8$

śākayāvakabhikṣāśī skandamūlaphalāśinah ${ }^{76}$

māsam e[[ka]]---samanvitạ̣ 9.9

mucyate 'sau ${ }^{77}$ mahāpāpāt kṣudrasiddhiñ ca vindate

dvimāsān madhyamā siddhir abdārddhād uttamā bhavet $\quad 9.10$

saṃvatsareṇa siddhis tu vidyāsiddhim avāpnuyāt

aṇimādyās tu jāyante siddhaiś ca saha modate $\quad 9.11$

īpsitāṃ labhate kāmān akāmo mokṣam āpnuyāt

\footnotetext{
72 vāmapārśve] KW; vāmapārśe N

73 dakṣiṇe pāde muñjamālāṃ tathā kațau] conj.; dakṣiṇe pa-ñjamālāṃstathā kațe N; dakșine ப muñjamālāṃ tathā kațau K; dakṣiṇe uṇṭhamālāṃstathā kaṭe W

$74 \quad{ }^{\circ}$ nārīśvara ${ }^{\circ}$ c conj.; ${ }^{\circ}$ nārīśvaraṃ NW; ${ }^{\circ}$ nārî́śvare $\mathrm{K}$

75 triṣkālaṃ] KW; triṣkāla ${ }^{\circ} \mathrm{N}$

76 skanda $\left.{ }^{\circ}\right] \mathrm{NW}$; $\mathrm{kanda}^{\circ} \mathrm{K}$

77 mucyate 'sau] em.; mucyate so NW; mucyate sa K
} 
The Goddess spoke:

From the MĀTR KĀ supernatural power and liberation can come about, O Lord. Tell me [how to attain] supernatural power and liberation through the MĀTRK KĀ. (1)

Why did you teach the mantras that arise from it? Tell me [the answer to] this excellent question. ... fruit to me. (2)

The Lord spoke:

Wearing half the dress of a woman and half [that of] a man, on one half, he should place [feminine] tresses, on one half, he should wear matted locks. (3)

On one half, there should be a forehead mark; on one half a [forehead] eye. A ring ( $v \bar{a} l i k \bar{a})$ [should be] in one ear; a [pendant] ear-ornament (kundalam) in one ear. He should put a trident (śülam) in his right hand and a breast on his left side, a girdle (mekhalām) on the left half, a bangle on the left arm, a woman's anklet on the left leg, a man's anklet on the right leg and a muñja-grass belt. At the hips, he should put a loin-cloth on the right and wear a woman's garment on the left. (4-6)

In the left hand, he should hold a winnowing fan in the observance of Ardhanāríśvara. Adopting this observance he should eat alms, keep his senses under control, be devoted to regular obligatory recitation and oblation, rejecting the receipt of gifts. $(7-8 b)$

He should venerate God three times [a day] and perform ablutions three times [a day]. Eating vegetables and barley-gruel, eating bulbs $\left(s k a n d a^{\circ}\left[=k a n d a^{\circ}\right]\right)$, roots and fruits, for one month ... (9)

He will be released from [the retributive force of] major transgressions; and he will attain low siddhis after two months, middling siddhis after half a year and high siddhis after a year; he will attain power over the spell (vidyāsiddhim). (10-11b)

The ability to make himself atomic, along with the others [of the yogic powers], will arise. He will take pleasure in the company of siddhas. He will attain the wishes he desires; if he is without desires, he will attain liberation. (11c-12b)

Although the words vrata, carya and vidyāvrata are none of them to be found, it is now clear to me that this passage makes implicit allusion to the structure now familiar to us from numerous other passages: the sädhaka propitiates a given mantra, here the MĀTRKĀ, by performing a timed religious observance involving unusual dress and diet, the rules of which are ideally held to be in some way appropriate to the mantra in question, and then becomes eligible for the pur- 
suit of particular siddhis. In the case of the MĀTRKĀ, adopting the appearance of Ardhanāriśvara is particularly appropriate because the MĀTRKĀ is made up of feminine vowels and masculine consonants, which, as is explained elsewhere in the Niśvāsa-corpus, are to be applied respectively to the left and right halves of the sādhaka's body before worship in a preliminary rite that prefigures what came to be called sakalikarana. ${ }^{78}$ The imitatio dei that is such a prominent feature of some observances, such as this one, now seems as if it should be more precisely characterised as identification with the mantra-deity being propitiated.

\section{Conclusion}

So what can be learned from the foregoing pages? In the beginning of this paper, I tried to emphasise the layered structure not only of the Niśvāsatattvasamhitāa, but also of the Guhyasütra itself. This incidentally means that we should not only be, as always, cautious in proposals for dating both this and related literature, but that we should perhaps also allow for a broad fourchette for the composition of this work, broad enough to cover the periods of composition of other related works. ${ }^{79}$ We should also bear in mind, while attempting to model the relative chronology of early Tantric literature, that it is the very latest layers of the Guhyasütra that provide the closest parallels with the grimoires of the Buddhist kriyātantras, in particular with the final chapter, 55, of the Mañjuśriyamūlakalpa (see Goodall and Isaacson 2016, passim).

We have also learned, I believe, about a further early stage in the history that precedes the familiar idea that Śaiva scriptures were divided into four sections treating knowledge, ritual, yoga and day-to-day behaviour ( jñāna, kriya $\bar{a}$, yoga, carya $)$. In the period of the redaction of the Niśvāsa, initiates were, de facto, all sādhakas seeking to harness the power of mantras and their cary $\bar{a}$ was not a matter of approved day-to-day behaviour, or "comportment," but rather of vrata-carya $\bar{a}$, the performance of timed religious observances. Such timed religious observances could be used, as in many other religious traditions, for expiation, but their primary use in the early Mantramārga was for

78 See Uttarasūtra 2.8 and annotation on pp. $35^{1-35^{2}}$ of Goodall, Sanderson, Isaacson et al. 2015 .

79 For the possibility that, for instance, the Rauravasūtrasangraha might have influenced the cosmographical chapters of the Guhyasūtra, see Goodall 2016, 89 ff. For the most recent discussion of the dating of the layered corpus that is the Niśvāsatattvasamhitā, see Goodall, Sanderson, Isaacson et al. 2015, 30-73. 
mantra-propitiation prior to other activities involving the mantras. Such preliminary mantra-propitiation could also be referred to by such expressions as vidyāvrata, puraścaryā and pūrvasevā. These notions about mantra-use and mantra-propitiation may be found reflected in a wide range of post-Niśvāsa pre-tenth-century writings. But once the intake of the religion had broadened to include many who were not occupied with spell-mastery at all, the term carya $\bar{a}$ in the tetrad of tantric topics also regained its (usually non-technical) sense of day-to-day "comportment." This shift in usage had taken place by the time of the composition of the Kirana, in other words by the beginning of the ninth century at the latest. ${ }^{80}$ Finally, the early Śaiva evidence furnished here suggests that this nexus of notions and labels is not such a fertile field as might have been supposed for those searching for evidence of instances of Buddhist influence upon the early Śaiva Mantramārga.

\section{Acknowledgements}

I am grateful to Harunaga Isaacson for the suggestions he made for improving this article.

\section{References}

\section{Primary Sources}

Kiranatantra. $\left(\mathrm{E}_{D}\right)$ Ti. Rā. Pañcāpageśaśivācārya and K.M. Subrahmanyaśāstrī, eds. śrīmat kiraṇāgamamahātantram. Śivāgamasiddhāntaparipālanasangha, no. 16. Devakōtțai, 1932.

Kiranatantra. National Archives, Kathmandu, MS 5-893, NGMPP Reel No. A 40/3, a tenth-century Nepalese palm-leaf manuscript (most recently described by Goodall 1998, lxxxiv-lxxxv).

Kubjikāmata. Teun Goudriaan and Jan A. Schoterman, eds. The Kubjikāmatatantra. Kulälikāmnāya Version. Critical Edition. Orientalia Rheno-Traiectina, no. 3o. Leiden; New York; København; Köln: Brill, 1988.

Jaiminigrhyasütra.W. Caland, ed. The Jaiminigrhyasūtra belonging to the Sāmaveda with extracts from the commentary edited with An introduction and translated for the first time into English. The Punjab Sanskrit Series 2. Lahore: Moti Lal Banarsi Dass, 1922.

8o For the observation that the Kirana belongs to a group of scriptures whose teachings can be found paraphrased in the Haravijaya, which was composed in Kashmir around 830 AD, see Sanderson 2001, 5-6. 
Tantrasadbhāva. Electronic edition of Mark Dyczkowski based on NGMPP Reel Nos. A 188/22, A 44/1, and A 44/2.

Niśvāsakārikā. Institut Français de Pondichéry, T. 17, 127 and 150. Paper transcripts in Devanāgarī script. (I am grateful to S.A.S. Sarma, R. Sathyanarayanan, Nibedita Rout and Nirajan Kafle, all of the Pondicherry Centre of the EFEO, for their help producing electronic transcriptions of these witnesses.)

Niśvāsatattvasaṃhitā. For the Mūlasūtra, Uttarasūtra and Nayasūtra, see Goodall, Sanderson, Isaacson et al. 2015 .

For the Guhyasūtra: NAK MS 1-227, N G MP P Reel No. A 41/14. Palm-leaf, early Nepalese 'Licchavi' script. Two apographs have been consulted throughout, both in Devanāgarī and on paper: NAK MS 5-2401, NGMPP Reel No. A 159/18, and Wellcome Institute for the History of Medicine, London, Sanskrit MS I.33. The verse and chapter numeration used in our annotation is that of Goodall's edition in progress. Diwakar Acharya, Peter Bisschop and Nirajan Kafle helped Goodall to produce the first complete transcription.

Niśvāsamukhatattvasaṃhitā. See Kafle 2015*.

Pāraskaragrhyasūtra. Mahādeva Gangādhar Bākre, ed. Grihya-sūtra by Parashar with five commentaries of Karka Upādhyāya, Jayarām, Harihar, Gadādhar and Vishvanāth as well as appendices called Vāpyādi-pratisthā Kandikā with Kāmdeva Bhāshya Showcha Sūtra, Snāna Sūtra with Harihar Bhāshya and Shradha Sūtra with three commentaries by Karka, Gadādhara and Shrādha Kāshika by Krishnamishra and Bhojana Sūtra. Reprint, New Delhi: Munshiram Manoharlal, 1982 [Bombay: Gujarati Printing Press, 1917].

Bodhāyanagrhyasūtra. R. Shama Sastri, ed. The Bodhâyana Grihyasutra. University of Mysore Oriental Library Publications Sanskrit Series, no. 32/55. Mysore: University of Mysore, 1920.

Matañga. N.R. Bhatt, ed. Matañgapārameśvarāgama (Kriyāpāda, Yogapāda et Caryāpāda) avec le commentaire de Bhațta Rāmakaṇțha. Publications de l'Institut Français d'Indologie, no. 65. Pondicherry: Institut Français d'Indologie, 1982.

Mohacūdottara. National Archives, Kathmandu, Ms 5-1977, NGMPP Reel No. A 182/2. This is a 1926 paper apograph manuscript in Devanāgarī script of a twelfth-century palm-leaf manuscript from Western India: National Archives, Kathmandu, Ms 11633, NGM P P Reel No. B 26/29 (for which see Tāntrikābhidhānakośa 2, s.v. gaṇa).

Vyomavatī. Gaurinath Sastri, ed. Vyomavatī of Vyomaśivācārya [Part Two]. M.M. Śivakumāraśāstri-Granthamālā, no. 6. Varanasi: Sampurnanand Sanskrit University, 1984.

Sarvajñānottara. Edition in progress by Dominic Goodall, based on various sources including IFP T. 334 [= L], Madras G OML R 16829 [= M], the early Nepalese manuscript (NGMPP A 43/12 [=N]), and manuscripts transmitting the twelfth-century commentary of Aghoraśiva. 
Svāyambhuvasūtrasangraha, Veṅkațasubrahmaṇyaśāstrī, ed. Svāyambhuvasūtrasan்graha. Mysore, 1937.

Svāyambhuvasūtrasangraha. (N) National Archives, Kathmandu, paṃ 348, NGMPP Reel No. A 3o/6, a Nepalese palm-leaf manuscript. See also Appendix to Sathyanarayanan 2015 .

\section{Secondary Sources}

Brunner, Hélène. 1985. Mrgendrāgama Section des rites et section du comportement avec la vṛtti de Bhațțanārāyaṇakaṇtha. Publications de l' Institut Français d' Indologie, no. 69. Pondicherry: Institut Français d'Indologie.

Brunner, Hélène. 1986. "Les membres de Śiva." Asiatische Studien/Études Asiatiques XL (2): 89-132.

Brunner, Hélène. 1992. "The Four Pādas of Śaivāgamas." The Journal of Oriental Research, Madras. Dr. S.S. Janaki Felicitation Volume vols. 56-72 (1986-1992): 26o-278.

Caland, Willem. 1922. See Jaiminigrhyasūtra.

Goodall, Dominic. 1998. Bhațta Rāmakanțha's Commentary on the Kiranatantra. Volume I: Chapters 1-6. Critical Edition and Annotated Translation. Publications du département d'indologie 86.1. Pondicherry: Institut Français de Pondichéry/École française d'Extrême-Orient.

Goodall, Dominic. 2004 The Parākhyatantra, a Scripture of the Saiva Siddhānta. A Critical Edition and Annotated Translation. Collection Indologie, no. 98. Pondicherry: Institut Français de Pondichéry/École française d'Extrême-Orient.

Goodall, Dominic. 2016. "How the Tattvas of Tantric Śaivism Came to Be 36: The Evidence of the Niśvāsatattvasamhitā." In Tantric Studies: Fruits of a Franco-German Collaboration on Early Tantra, edited by Dominic Goodall and Harunaga Isaacson, 77-111. Collection Indologie, no. 131/Early Tantra Series, no. 4. Pondicherry: Institut Français de Pondichéry/École française d' Extrême-Orient/Asien-Afrika-Institut, Universität Hamburg.

Goodall, Dominic, Alexis Sanderson and Harunaga Isaacson. 2015. The Niśvāsatattvasamhitā. The Earliest Surviving Śaiva Tantra, Volume 1, A Critical Edition \& Annotated Translation of the Mūlasūtra, Uttarasūtra \& Nayasūtra, edited by Dominic Goodall, in collaboration with Alexis Sanderson \& Harunaga Isaacson, with contributions of Nirajan Kafle, Diwakar Acharya \& others. Collection Indologie, no. 128/ Early Tantra Series, no. 1. Pondicherry: Institut Français de Pondichéry/École française d'Extrême-Orient/Asien-Afrika-Institut, Universität Hamburg.

Goodall, Dominic, and Harunaga Isaacson. 2016. "On the Shared 'Ritual Syntax' of the Early Tantric Traditions." In Tantric Studies: Fruits of a Franco-German Collaboration on Early Tantra, edited by Dominic Goodall and Harunaga Isaacson, 1-76. Collection Indologie, no. 131/Early Tantra Series, no. 4. Pondicherry: Institut Français de Pondichéry/École française d'Extrême-Orient/Asien-Afrika-Institut, Universität Hamburg. 
Isaacson, Harunaga. 2015. See Goodall, Sanderson, Isaacson et al. 2015.

Isaacson, Harunaga. 2016. See Goodall and Isaacson 2016.

Kafle, Nirajan. 2015*. The Niśvāsamukha, the Introductory Book Prefacing the Niśvāsatattvasamhitā, Critically Edited and Furnished with an Annotated Translation and an Appendix Giving an Edition of Chapters 5-9 of the Sivadharmasangraha. Ph.D. thesis, the University of Leiden.

Kiss, Csaba. 2015. The Brahmayamala Tantra or Picumata, Volume Two. The Religious Observances and Sexual Rituals of the Tantric Practitioner: chapters 3,21 and 45. Collection Indologie, no. 130/ Early Tantra Series, no. 3. Pondicherry: Institut Français de Pondichéry/École française d' Extrême-Orient/Asien-Afrika-Institut, Universität Hamburg.

Nemec, John. 2014. Review of Wedemeyer 2013, Journal of Religion 94 (2): 271-273.

Olivelle, Patrick. 2005. Manu's Code of Law. A Critical Edition and Translation of the Mānava-Dharmaśāstra ... With the Editorial Assistance of Suman Olivelle. New York: Oxford University Press.

Sanderson, Alexis. 2001. "History through Textual Criticism in the Study of Śaivism, the Pañcarātra and the Buddhist Yoginītantras." In Les sources et le temps. Sources and Time. A colloquium. Pondicherry 11-13 January 1997, edited by François Grimal, 1-47. Publications du département d'Indologie, no. 91. Pondicherry: Institut Français de Pondichéry/École française d'Extrême-Orient.

Sanderson, Alexis. 2006. "The Lākulas: New Evidence of a System Intermediate Between Pāñcārthika Pāśupatism and Āgamic Śaivism." Indian Philosophical Annual 24 (2003-2005): 143-217.

Sanderson, Alexis. 20o6b. "The Date of Sadyojyotis and Bṛhaspati." Cracow Indological Studies 8: 39-91.

Sanderson, Alexis. 2009. "The Śaiva Age." In Genesis and Development of Tantrism, edited by Shingo Einoo, 41-349. Institute of Oriental Culture Special Series, no. 23. Tokyo: Institute of Oriental Culture, University of Tokyo.

Sanderson, Alexis. 2015. See Goodall, Sanderson, Isaacson et al. 2015.

Sathyanarayanan, R., and Dominic Goodall. 2015. Śaiva Rites of Expiation. A First Edition and Translation of Trilocanaśiva's Twelfth-century Prāyaścittasamuccaya (with a transcription of Hṛdayaśiva's Prāyaścittasamuccaya), critically edited \& translated by R. Sathyanarayanan, with an introduction by Dominic Goodall. Collection Indologie, no. 127. Pondicherry: Institut Français de Pondichéry /École française d'ExtrêmeOrient.

Tāntrikābhidhānakośa. 2004. Tāntrikābhidhānakośa II. Dictionnaire des termes techniques de la littérature hindoue tantrique. A Dictionary of Technical Terms from Hindu Tantric Literature. Wörterbuch zur Terminologie hinduistischer Tantren, ed. Hélène Brunner†, Gerhard Oberhammer, André Padoux. Sitzungsberichte der philosophisch-historischen Klasse 714, Beiträge zur Kultur- und Geistesgeschichte Asiens 44. Vienna: Österreichische Akademie der Wissenschaften. 
Tāntrikābhidhānakośa. 2013. Tāntrikābhidhānakośa III. Dictionnaire des termes techniques de la littérature hindoue tantrique. A Dictionary of Technical Terms from Hindu Tantric literature. Wörterbuch zur Terminologie hinduistischer Tantren, sous la direction de Dominic Goodall et Marion Rastelli. Österreichische Akademie der Wissenschaften, Philosophisch-historische Klasse, Sitzungsberichte, 839. Band. Beiträge zur Kultur- und Geistesgeschichte Asiens 76. Vienna: Verlag der Österreichischen Akademie der Wissenschaften.

Törzsök, Judit. 1999*. 'The Doctrine of Magic Female Spirits'. A Critical Edition of Selected Chapters of the Siddhayogeśvarimata(tantra) with Annotated Translation and Analysis. Ph.D. thesis, the University of Oxford.

Wedemeyer, Christian K. 2013. Making Sense of Tantric Buddhism. History, Semiology, \& Transgression in the Indian Traditions. New York: Columbia University Press. 